\title{
Glucocorticoid Regulation of Insulin Receptor Gene Transcription in IM-9 Cultured Lymphocytes
}

\author{
Alex R. McDonald and Ira D. Goldfine \\ Cell Biology Laboratory and Department of Medicine, Mount Zion Hospital and Medical Center, San Francisco, California 94115; \\ and Departments of Medicine and Physiology, University of California San Francisco, San Francisco, California 94143
}

\begin{abstract}
We have reported that glucocorticoids increase steady state insulin receptor mRNA levels in target cells. In the present study using IM-9 cultured human lymphocytes, we investigated the mechanism responsible for this glucocorticoid mediated increase in insulin receptor mRNA levels. Incubation of IM-9 cells with $100 \mathrm{nM}$ dexamethasone for $4 \mathrm{~h}$ stimulated a parallel increase in both polysomal and nuclear insulin receptor RNAs indicating that glucocorticoids did not alter the nuclear transport of insulin receptor RNA. Dexamethasone did not alter insulin receptor $\mathrm{mRNA}$ half life $\left(t_{1 / 2}=140 \pm 20 \mathrm{~min}\right)$, indicating that glucocorticoids did not influence mRNA stability. Furthermore, the dexamethasone-induced increase in insulin receptor mRNA levels was not blocked by pretreatment of cells with cycloheximide indicating that the glucocorticoid effect was independent of new protein synthesis. When the labeled transcripts from nuclear run-off incubations were then hybridized to immobilize human insulin receptor cDNA, a three- to fourfold increase in transcriptional activity was observed. This transcriptional effect occurred before the increase in steady state insulin receptor mRNA levels and over the same range of dexamethasone concentrations. These studies indicate therefore a direct effect of glucocorticoids on insulin receptor gene transcription, and demonstrate that the insulin receptor gene is under hormonal control.
\end{abstract}

\section{Introduction}

The polypeptide hormone insulin produces a wide range of effects both in the intact organism and in cultured cells (1). The interaction of insulin with target cells is mediated by a receptor located on the plasma membrane which serves a critical role both in directing insulin to specific target tissues and in initiating the response of these tissues to the hormone $(2,3)$. The insulin receptor is of major importance in certain states of insulin resistance in humans, in which qualitative and quantitative abnormalities of the receptor may lead to defective transmembrane signaling $(4,5)$. In addition, the insulin receptor is regulated by hormones and other agents (3-5).

The insulin receptor is a glycoprotein of $\sim 400 \mathrm{kD}$, and is a tetramer composed of two alpha $(130 \mathrm{kD})$ and two beta $(95$

Address reprint requests to Dr. Goldfine, Cell Biology Laboratory, Mount Zion Hospital and Medical Center, P.O. Box 7921, San Francisco, CA 94120.

Received for publication 5 June 1987 and in revised form 14 September 1987.

J. Clin. Invest.

(c) The American Society for Clinical Investigation, Inc.

0021-9738/88/02/0499/06 \$2.00

Volume 81, February 1988, 499-504
kD) subunits $(6,7)$. One alpha and one beta subunit are derived from a common precursor protein that has a minimum molecular weight of $153 \mathrm{kD}$ as derived from cDNA analysis (8, 9). The alpha subunit is totally extracellular and binds insulin while the beta subunit is transmembrane and contains tyrosine kinase activity (6-9).

At present little is known about the hormonal regulation of insulin receptors at the level of gene expression. Previously in both hepatocytes and lymphocytes it was reported that glucocorticoids enhanced insulin receptor biosynthesis $(10,11)$. Moreover, we have recently demonstrated, in IM-9 lymphocytes and AR42J pancreatic acinar cells, that glucocorticoids increase insulin receptor synthesis by increasing insulin receptor mRNA levels (12). However, the mechanism whereby glucocorticoids stimulate insulin receptor mRNA levels has not been investigated.

After entering target cells, glucocorticoid hormones first bind to intracellular receptors (13-15). The steroid hormonereceptor complex then interacts with glucocorticoid recognition elements (GRE) ${ }^{1}$ on DNA causing either an increase or decrease in the transcription of several genes (13-15). In addition to this mechanism of gene regulation it has been reported that glucocorticoids can influence specific mRNA levels at a posttranscriptional level, including alteration of RNA stability (16-18) and stimulation of the transport of specific RNA species from the nucleus to the cytoplasm (19). Also, in certain circumstances, glucocorticoid stimulation of transcription may be dependent on ongoing protein synthesis (20).

In the present study we have investigated the mechanism of glucocorticoid-stimulation of insulin receptor mRNA levels in IM-9 lymphocytes. Transcription run-off assays and mRNA half life studies were performed. These data indicate that glucocorticoids have a primary effect on insulin receptor gene transcription.

\section{Methods}

Cell culture. IM-9 lymphocytes were grown as previously described (12) except that to improve cell growth and viability minimal essential media was replaced by RPMI 1640 media (11). Cells were routinely maintained at a density of $5 \times 10^{5}$ cells $/ \mathrm{ml}$ and during experiments the cell concentration was increased to $1 \times 10^{6}$ cells $/ \mathrm{ml}$.

Preparation of RNA from whole cells, polysomes, and nuclei. RNA was prepared from whole cells using the proteinase $\mathrm{K}$ method in the presence of SDS (21). RNA concentrations were estimated using absorbance at $260 \mathrm{nM}(1.0 \mathrm{OD}=40 \mu \mathrm{g})$. Polysomes were prepared by a slight modification of the magnesium precipitation method (22). In brief, $5 \times 10^{8}$ cells were washed in phosphate-buffered saline, at $4^{\circ} \mathrm{C}$ and homogenized in lysis buffer as previously described (22). After precipitation of the nuclear pellet, the polysomes were centrifuged

1. Abbreviations used in this paper: GRE, glucocorticoid recognition elements. 
through a 1.0-M sucrose cushion (rather than the 0.2-M cushion) (22). The polysomal pellet was then resuspended in $1 \mathrm{ml}$ of $20 \mathrm{mM}$ Hepes, pH 7.5; sodium acetate and SDS were added to final concentrations of $0.1 \mathrm{M}$ and $0.5 \%$, respectively. The suspension was extracted with phenol and chloroform, and the aqueous phase was precipitated overnight with 2 vol of $100 \%$ ethanol at $-20^{\circ} \mathrm{C}$.

Nuclear RNA was prepared from $5 \times 10^{8}$ isolated nuclei using the guanidinium-cesium chloride method (23).

Slot blots and Northern transfers. For Northern transfers total $\mathrm{RNA}^{2}$ was denatured in formaldehyde, subjected to electrophoresis in $1 \%$ agarose and transferred to nitrocellulose paper (12). For "slot blots" RNA was denatured as described by Thomas (24) and various dilutions of RNA were immobilized to nitrocellulose using a slot blot apparatus (Schleicher \& Schuell, Keene, NH). Yeast tRNA was added as a carrier to samples when the final RNA concentration was $<1$ $\mu \mathrm{g} / \mathrm{ml}$.

Nick translation and hybridization of filters. These studies used two human insulin receptor cDNA probes, 18.2 and $13.2(1 \mathrm{~kb}$ and $4.2 \mathrm{~kb}$, respectively), a kind gift from Dr. G. I. Bell (University of Chicago) and spanning the entire open reading frame of the receptor and extending into the 3 -untranslated region (25). In addition these studies employed an $8.7-\mathrm{kb}$ plasmid containing the $5^{\prime}$ portion of the rat $18 \mathrm{~s}$ ribosomal RNA gene pDF15 (26) a kind gift from Dr. A. P. Bollon (Wadley Institutes of Molecular Medicine, TX). These cDNA probes were nick-translated (labeling kit; Bethesda Research Laboratories, Gaithersburg, MD) to specific activities of $1 \times 10^{9} \mathrm{cpm} / \mu \mathrm{g}$. Filters containing RNA were prehybridized and hybridized with either $1 \times 10^{7} \mathrm{cpm} / \mathrm{ml}$ insulin receptor cDNAs or $5 \times 10^{6} \mathrm{cpm} / \mathrm{ml}$ ribosomal genomic DNA and washed as previously described (12).

Isolation of nuclei and run-off assays. Nuclei were prepared from 1 $\times 10^{8}$ cells by washing twice in buffered saline followed by resuspension in lysis buffer (27) containing $10 \mathrm{mM}$ Tris (pH 7.4) $10 \mathrm{mM} \mathrm{NaCl}$, $5 \mathrm{mM} \mathrm{MgCl}_{2}$, and $0.5 \% \mathrm{NP}-40$. Cells were homogenized in a Dounce homogenizer with 8 strokes of the loose pestle and a nuclear pellet was obtained by centrifugation at $800 \mathrm{~g}$ for $5 \mathrm{~min}$. Visual inspection under a phase contrast microscope revealed no intact cells. Nuclei were resuspended in storage buffer ( $40 \%$ glycerol, $50 \mathrm{mM}$ Tris ( $\mathrm{pH} 8.3$ ), $5 \mathrm{mM}$ $\mathrm{MgCl}_{2}, 0.1 \mathrm{mM}$ EDTA) and were either used immediately or stored at $-70^{\circ} \mathrm{C}$.

Transcription assays were performed using $5 \times 10^{7}$ nuclei in each reaction as described (27). RNA products were purified using DNAase, proteinase $K$ in the presence of SDS, and salt precipitation according to the procedure of Groudine et al. (27). $5 \mu \mathrm{g}$ of either the control plasmid pBr327, the plasmid containing cDNA to $\beta$-actin (28), or the plasmid containing the $5^{\prime}$ end of the insulin receptor (18.2) were denatured by heating to $65^{\circ} \mathrm{C}$ for $1 \mathrm{~h}$ in $0.2 \mathrm{M} \mathrm{NaOH}$, neutralized with an equal volume of cold $3 \mathrm{M}$ sodium acetate, and applied to nitrocellulose using a slot-blot manifold. The slots were washed with $500 \mu \mathrm{l}$ of $10 \times$ SSC and the filters baked under vacuum at $80^{\circ} \mathrm{C}$ for $2 \mathrm{~h}$. The filters were then prehybridized and hybridized in $2 \mathrm{ml}$ of buffer as described (27) except that hybridizations were performed in $6 \times 5 \mathrm{ml}$ tissue culture plates. After hybridization, filters were washed sequentially in

2. In contrast to our previous study where we used poly(A) ${ }^{+}$RNA for Northern blots and slot blots, in the present study we used total cellular RNA. This use of total cellular RNA allowed a more rapid measurement of mRNA levels, and reduced the potential variability in poly $(\mathrm{A})^{+}$RNA content that can occur following its passage through oligo $d(t)$ cellulose. This variability requires the normalization of data with a second cDNA, such as that for $\beta$-actin whose mRNA levels are unaffected by the experimental conditions (12). The only difference we observed between this study and the previous study, was that maximum steady state insulin receptor mRNA levels were achieved less rapidly in the present study. This slight change in time course is due to the fact that in the present study, cells were grown in RPMI 1640 medium supplemented with $10 \%$ fetal calf serum (11), rather than minimal essential medium supplemented with $10 \%$ calf serum (12).
$100 \mathrm{ml}$ volumes of $2 \times \mathrm{SSC}(20 \times \mathrm{SSC}=3 \mathrm{M} \mathrm{NaCl}, 0.3 \mathrm{M}$ sodium citrate) at $65^{\circ} \mathrm{C}$ for $1 \mathrm{~h}, 2 \times \mathrm{SSC}$ with $10 \mu \mathrm{g} / \mathrm{ml}$ ribonuclease $\mathrm{A}$ at $37^{\circ} \mathrm{C}$ for $30 \mathrm{~min}$, and $0.5 \times \mathrm{SSC}$ with $0.1 \%$ SDS for $2 \mathrm{~h}$ at $65^{\circ} \mathrm{C}$.

Preparation of sense and antisense $c R N A$. The $5^{\prime}$ insulin receptor cDNA insert (18.2) was cloned into the Eco RI site of the SP6 polymerase recognition plasmid pSP64 (Promega Biotech, Madison, WI). The resultant plasmids pSPIR-3 and pSPIR- 6 contained both orientations of the cDNA insert resulting in the production of both sense and antisense RNA, respectively. Large quantities of RNA were produced using the technique of Melton (29). RNA was purified by treating the $100-\mu 1$ reaction volume with $10 \mathrm{U}$ of ribonuclease-free DNAse 1 (Promega Biotech), phenol/chloroform extraction, passage through a $1 \mathrm{ml}$ Sephadex G-50 spin column and overnight precipitation with 2.5 vol of $100 \%$ ethanol.

\section{Results}

Effects of dexamethasone on insulin receptor steady state $m R N A$ levels. In this study, using total RNA prepared from IM-9 cells, we investigated the effects of dexamethasone on steady state insulin receptor mRNA levels. To determine the sensitivity of IM-9 cells to this synthetic glucocorticoid, cells were incubated for $4 \mathrm{~h}$ with various concentrations of the glucocorticoid, total RNA was prepared, and the level of insulin receptor mRNA determined by slot-blot analysis (Fig. 1). One half maximal stimulation was detected at $5 \mathrm{nM}$ dexamethasone and maximal stimulation was observed at $100 \mathrm{nM}$. During this incubation period, ribosomal RNA levels were either unchanged or slightly decreased.

Since insulin receptor mRNA migrates as multiple bands on agarose gels, we carried out Northern transfers of total IM-9 cell RNA. Autoradiographs of these transfers displayed the multiple band pattern of insulin receptor message as reported $(8,9,12)$ with major bands at 11.0 and $8.5 \mathrm{~kb}$ (Fig. 1). Both of the major bands increased in response to dexamethasone treatment.

To determine the time course of dexamethasone stimulation of insulin receptor mRNA levels, IM- 9 cells were incubated for up to $24 \mathrm{~h}$ with $100 \mathrm{nM}$ dexamethasone (Fig. 2). One-half maximal stimulation was observed after $4 \mathrm{~h}$ and a maximal stimulation was seen after 8-24 h of treatment.

Studies on potential posttranscriptional mechanisms. Recently it has been demonstrated that steroid hormones can influence mRNA levels by altering the stability of specific mRNA species (16-18). Accordingly, studies were carried out to investigate insulin receptor half-life, and possible dexamethasone effects on this function. First cells were preincubated in the presence or absence of $100 \mathrm{nM}$ dexamethasone for $4 \mathrm{~h}$. Ongoing transcription was then inhibited by the addition of 5 $\mu \mathrm{g} / \mathrm{ml}$ actinomycin $\mathrm{D}(30)$, and at subsequent time points the cells were removed and the level of insulin receptor mRNA measured (Fig. 3). The insulin receptor mRNA decreased to one-half of its initial value after $140 \pm 20 \mathrm{~min}(n=3$, mean \pm SEM). Preincubation and continued incubation with dexamethasone did not alter the insulin receptor mRNA halflife (135 $\pm 22 \mathrm{~min})$.

Another posttranscriptional mechanism that may influence mRNA levels is the altered efflux of insulin receptor mRNA from the nucleus to the cytoplasm (19). To test for this possibility, cells were incubated for $4 \mathrm{~h}$ in the presence or absence of $100 \mathrm{nM}$ dexamethasone and total nuclear RNA prepared. These studies indicated that dexamethasone increased nuclear RNA levels (Fig. $4 A$ ). Polysomal RNA was prepared from cells treated as for the nuclear RNA determina- 


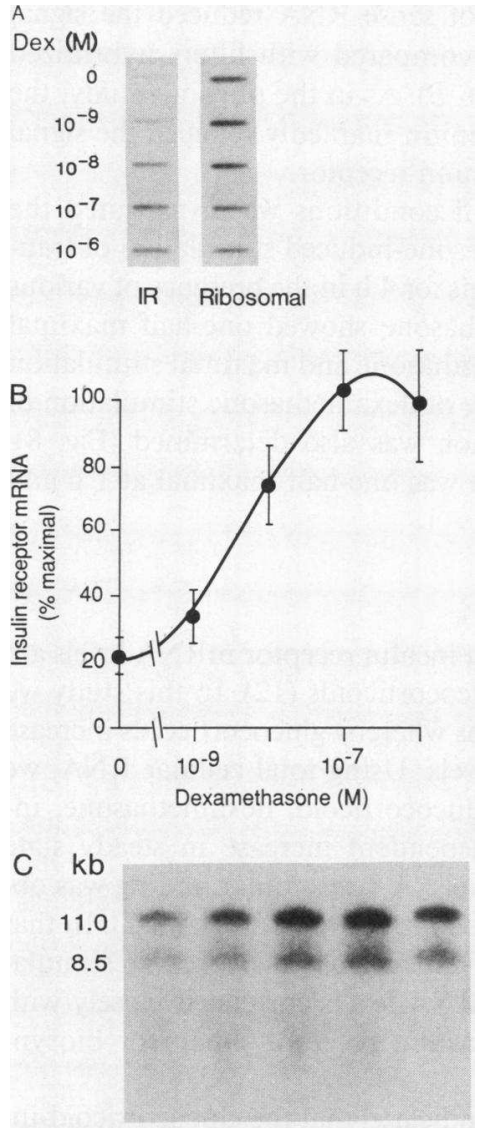

$\operatorname{Dex}(\mathrm{M}) \quad 0 \quad 10^{-9} 10^{-8} 10^{-7} 10^{-6}$
Figure 1. The dose dependence of dexamethasonestimulation of insulin receptor mRNA levels. IM-9 cells were incubated for $4 \mathrm{~h}$ in the presence of various concentrations of dexamethasone (Dex). $(A)$ Total RNA was applied to nitrocellulose filters with a slot blot apparatus. $5 \mu \mathrm{g}$ of RNA was applied to the left hand lanes and probed with a labeled insulin receptor (IR) cDNA. 5 ng of RNA was applied to the right hand lanes and probed with labeled ribosomal genomic DNA. (B) Densitometric scan of slot blots. The mean \pm SEM of three experiments is shown. (C) Autoradiogram of the Northern transfer of $5 \mu \mathrm{g}$ total RNA/lane probed with labeled insulin receptor cDNA.

tions. As was observed in whole cell RNA and nuclear RNA, dexamethasone stimulated polysomal insulin receptor mRNA levels to a similar extent (Fig. $4 \mathrm{~B}$ ). Northern transfers of polysomal RNA showed the presence of the two major RNA species previously observed in transfers of both total and poly $(\mathrm{A})^{+}$ RNA from whole cells (12). This finding suggested that both major species of insulin receptor mRNA are translated into insulin receptor protein products.

To determine whether the dexamethasone stimulated increase in receptor mRNA levels was dependent upon ongoing protein synthesis incubations were performed in the presence of cycloheximide, an inhibitor of protein synthesis. Cells were

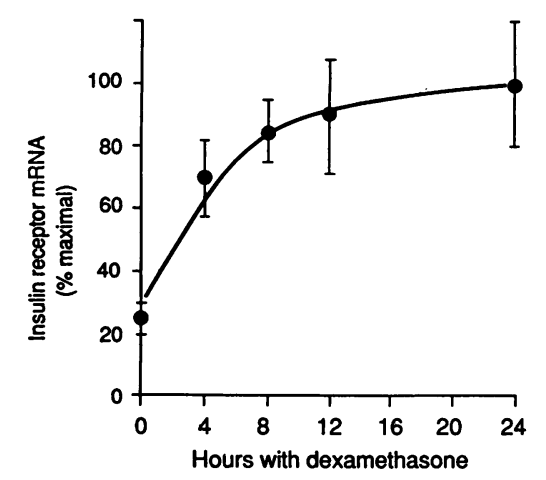

Figure 2. Time course of dexamethasone-stimulation of insulin receptor mRNA levels. IM-9 cells were incubated for the indicated times with $100 \mathrm{nM}$ dexamethasone (Dex), total RNA was prepared, and three dilutions $(10,5$, and 2.5 $\mu \mathrm{g})$ at each time point were slot-blotted, hybridized with labeled insulin receptor cDNA, washed, and autoradiographs obtained. The mean \pm SEM of three experiments is shown.

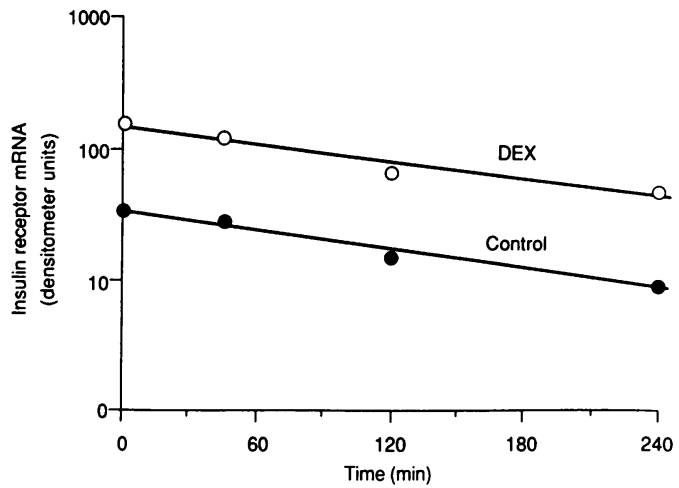

Figure 3. Insulin receptor mRNA life studies. IM-9 cells were incubated in the presence or absence of $100 \mathrm{nM}$ dexamethasone (Dex) for $4 \mathrm{~h}$ followed by the addition of $5 \mu \mathrm{g} / \mathrm{ml}$ actinomycin. At the times indicated cells were removed, RNA was denatured, and slotblotted at three dilutions $(10,5$, and $2.5 \mu \mathrm{g})$ for insulin receptor (IR) determinations. A representative of three experiments is shown.

preincubated for $30 \mathrm{~min}$ with $10 \mu \mathrm{g} / \mathrm{ml}$ cycloheximide, a concentration in these cells that inhibits $>95 \%$ of ongoing protein synthesis (data not shown), and then the cells were incubated for a further $4 \mathrm{~h}$ in the presence or absence of $100 \mathrm{nM}$ dexamethasone (Fig. 5). Incubation of cells with cycloheximide had no effect upon the dexamethasone stimulated increase in receptor mRNA levels.

Insulin receptor transcription studies. Since the above data indicated that stimulation of mRNA levels by dexamethasone was not posttranscriptional, nuclear run-off determinations were performed. In nuclear run-off transcription assays, transcripts that are initiated in the whole cell are elongated in isolated nuclei and reflect the ongoing rate of transcription (30). In order to examine the transcription system two types of validation experiments were performed (Fig. 6). In the first series of experiments $5 \mu \mathrm{g}$ of the insulin receptor cDNA plasmid $\mathrm{pBr} 327$ (the cloning vector used for the insulin receptor), and $\beta$-actin cDNA plasmids (we previously have demonstrated (12) that $\beta$-actin mRNA levels are unchanged in response to incubation with dexamethasone), were immobilized on nitrocellulose and hybridized with the nuclear transcription run-off

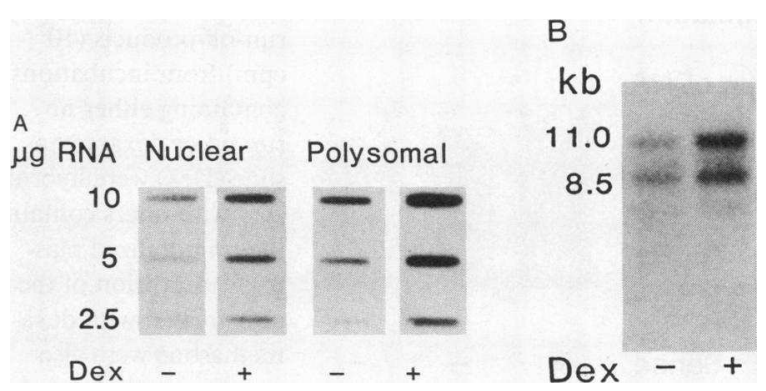

Figure 4. Determination of dexamethasone effects upon insulin receptor mRNA levels in nuclei and polysomes. IM-9 cells were incubated in the presence or absence of dexamethasone (Dex) for $4 \mathrm{~h}$. Nuclear RNA was prepared from one half of the cells and polysomal RNA was obtained from the other half. $(A)$ Three concentrations of RNA (10.0, 5.0, and $2.5 \mu \mathrm{g})$ were slot-blotted onto nitrocellulose filters and probed with labeled insulin receptor cDNA. These results are a representative of three experiments. $(B)$ Autoradiograms of a Northern transfer of $5 \mu \mathrm{g}$ of polysomal RNA probed with insulin receptor cDNA. 


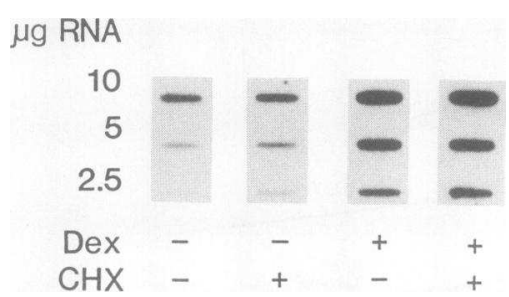

Figure 5. Effect of inhibition of protein synthesis upon insulin receptor mRNA levels. Cells were preincubated in the presence or absence of $10 \mu \mathrm{g} / \mathrm{ml} \mathrm{cy}$ cloheximide (CHX) for 30 min and then incubated for a further $4 \mathrm{~h}$ in the presence or absence of $100 \mathrm{nM}$ dexamethasone (Dex). Total RNA was prepared and three concentrations of RNA $(10,5$, and $2.5 \mu \mathrm{g})$ were slot-blotted onto nitrocellulose filters and hybridized with the labeled insulin receptor cDNA. A representative experiment of four experiments is shown.

products (Fig. $6 \mathrm{~A}$ ). Nuclei from dexamethasone stimulated cells gave products that increased the insulin receptor signal over the corresponding unstimulated insulin receptor control signal. In contrast the $\beta$-actin signal remained unchanged, and no significant signal was seen with $\mathrm{pBr} 327$. The addition of 2 $\mu \mathrm{g} / \mathrm{ml} \alpha$-amanitin to the nuclear incubation, a concentration that preferentially inhibits RNA polymerase II (30), markedly reduced the signal obtained. This finding indicated that the insulin receptor transcription signal was produced by RNA polymerase II, and therefore was either messenger RNA or its precursor.

In the second series of experiments, $30 \mu \mathrm{g}$ of either sense RNA or antisense RNA (prepared using SP6 polymerase primed transcription), was hybridized for $2 \mathrm{~d}$ to nitrocellulose strips containing either $\beta$-actin cDNA ( $5 \mu \mathrm{g}$ ) or three concentrations of denatured insulin receptor $\operatorname{cDNA}(5,2.5$, and 1.25 $\mu \mathrm{g})$. The filters were then hybridized with the in vitro RNA

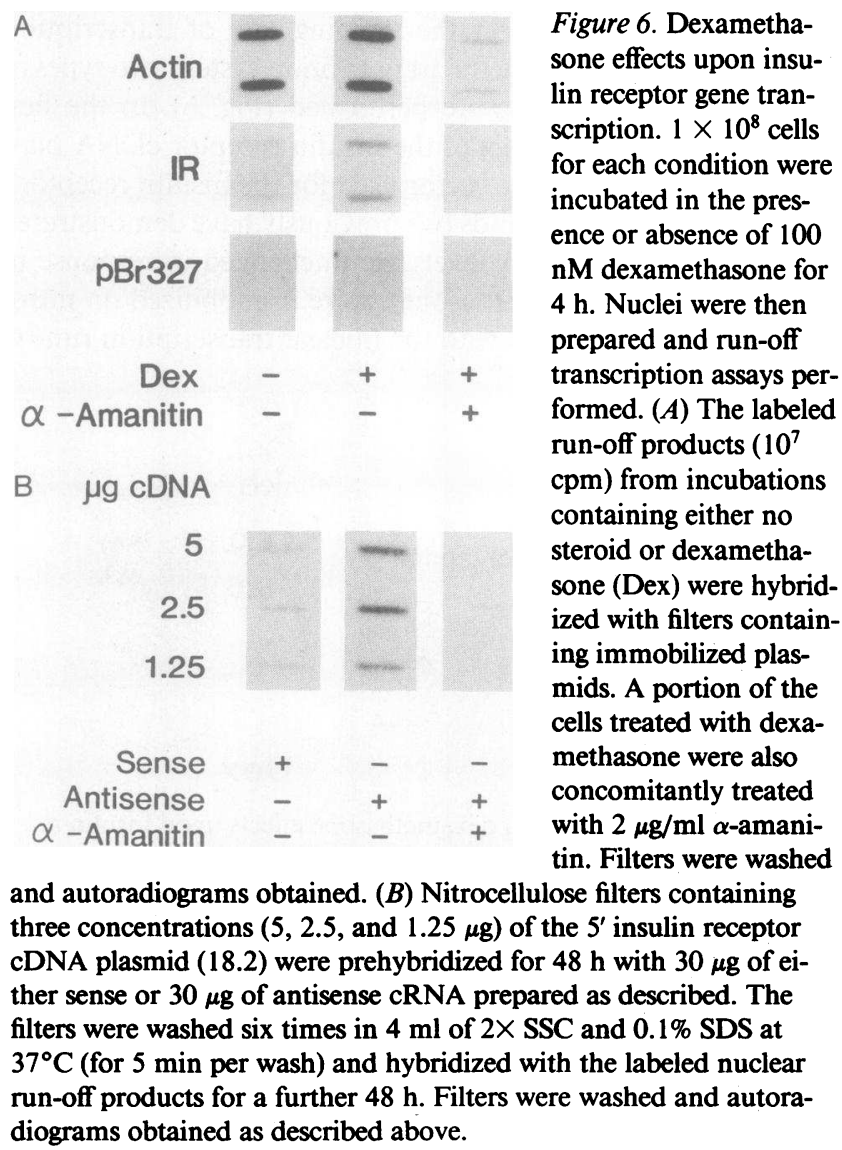

run-off products from dexamethasone-treated cells. The preincubation with $30 \mu \mathrm{g}$ of sense RNA reduced the signal obtained by $>75 \%$ when compared with filters hybridized with antisense cRNA (Fig. $6 \mathrm{~B}$ ). As in the previous study, the inclusion of $2 \mu \mathrm{g} / \mathrm{ml} \alpha$-amanitin markedly reduced the signal for both $\beta$-actin and the insulin receptor.

Using the above run-off conditions we investigated the dose-response of dexamethasone-induced stimulation of transcription (Fig. 7). Incubations for $4 \mathrm{~h}$ in the presence of various concentrations of dexamethasone showed one-half maximal stimulation at $5 \mathrm{nM}$ dexamethasone and maximal stimulation at $100 \mathrm{nM}$. The time course of dexamethasone stimulation of insulin receptor transcription was also determined (Fig. 8). Transcriptional stimulation was one-half maximal at $1 \mathrm{~h}$ and maximal at $2 \mathrm{~h}$.

\section{Discussion}

We previously reported that insulin receptor mRNA levels are under the regulation of glucocorticoids (12). In this study we investigated the mechanisms whereby glucocorticoids increase insulin receptor mRNA levels. Using total cellular RNA, we found that the synthetic glucocorticoid, dexamethasone, induced a time- and dose-dependent increase in steady state insulin receptor mRNA levels. A very similar finding was observed in our previous paper with poly(A) ${ }^{+}$RNA (12). In that study the time and dose dependence of glucocorticoid stimulation of insulin receptor mRNA levels correlated closely with glucocorticoid-increased insulin receptor precursor biosynthesis.

Four lines of evidence indicated that the glucocorticoid-induced increase in insulin receptor mRNA levels was due to increased insulin receptor gene transcription and was not due to posttranscriptional mechanisms. First, we observed that glucocorticoids did not alter the half-life of insulin receptor mRNA. These half life studies were carried out because there is evidence that steroid hormones can enhance the stability of several mRNA species including human growth hormone (16) vitellogenin (17), and casein (18).

The half-life of approximately $2 \mathrm{~h}$ for the insulin receptor mRNA was relatively short, and similar to that reported for casein (18). This half-life for the insulin receptor was shorter

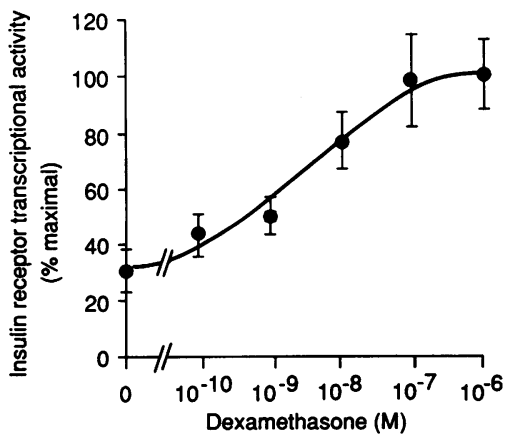

Figure 7. The dose dependence of dexamethasone stimulation of insulin receptor gene transcription. Cells were incubated with various concentrations of dexamethasone for $4 \mathrm{~h}$ and nuclei were prepared from each concentration. Identical strips of nitrocellulose filters were prepared by slot-blotting duplicate $5-\mu \mathrm{g}$ aliquots of plasmids containing insulin receptor cDNA (18.2). Filters were prehybridized and hybridized for $48 \mathrm{~h}$ in buffer containing $1 \times 10^{7} \mathrm{cpm}$ of run-off products. Autoradiograms were scanned by laser densitometer. The mean \pm SEM of three experiments is shown. 


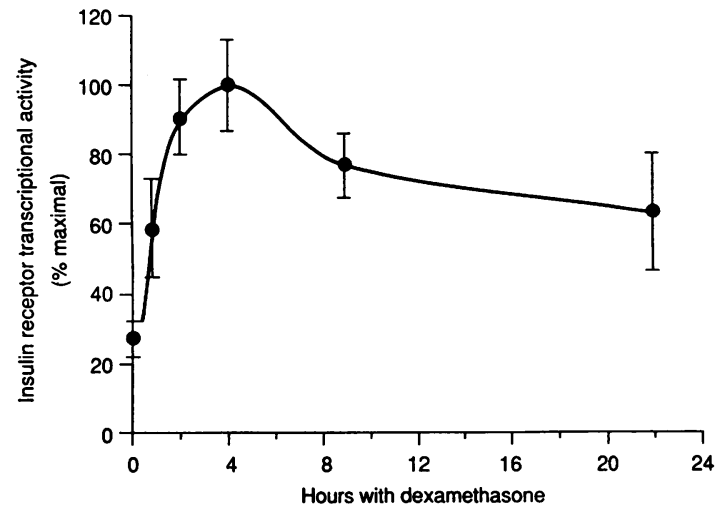

Figure 8 . The time course of dexamethasone stimulation of insulin receptor gene transcription. Cells were incubated with $100 \mathrm{nM}$ dexamethasone for up to $22 \mathrm{~h}$ and nuclei prepared. Transcription assays were performed as in Fig. 7 and the products hybridized against immobilized plasmids containing insulin receptor cDNA. The mean \pm SEM of three experiments is shown.

than some other known mRNAs regulated by steroid hormones including vitelligenin (17), human growth hormone (16), and ribosomal RNA. However, this half-life for the insulin receptor is not as short as the 15-25-min half lives of certain oncogenes and enzymes $(27,31)$.

Second, dexamethasone increased the content of both nuclear and polysomal insulin receptor mRNA. These studies were carried out because it has been shown that dexamethasone increases levels of several liver polysomal mRNA species (including $\alpha-2 \mu$ globulin) with a concomitant decrease in nuclear RNA levels (19). In these studies it was suggested therefore that glucocorticoids may act posttranscriptionally by enhancing the transfer of mRNA out of the nucleus. Since in the present study, both nuclear and polysomal levels of insulin receptor mRNA increased concomitantly, the data suggested that enhanced nuclear transport of insulin receptor mRNA was not influenced by glucocorticoids.

Multiple species of insulin receptor mRNA have been detected in human, rat, and mouse tissues $(8,9,12)$. These multiple species may reflect either different sites of transcriptional initiation, differential RNA splicing, different length poly(A) tails or a combination thereof. In IM-9 lymphocytes we found two major species of 11.0 and $8.5 \mathrm{~kb}$ (12). In the present study both of these species were increased by dexamethasone and associated with polysomes suggesting that both mRNA species were active in the biosynthesis of insulin receptor precursors.

Third, we found that pretreatment with the inhibitor of protein synthesis, cycloheximide, did not block the effect of dexamethasone on insulin receptor mRNA levels. This observation suggested that dexamethasone was directly stimulating the insulin receptor gene. Glucocorticoids have been observed to have secondary effects on the transcription of certain genes (20), for instance, the glucocorticoid-induced increase in $\alpha-2 \mu$ globulin mRNA (32) and pancreatic amylase mRNA (Logsdon, C. D., K. Perot, and A. R. McDonald. Submitted.) were blocked by the pretreatment of cells with cycloheximide.

Fourth, nuclear run-off transcription assays indicated that glucorticoids directly influenced insulin receptor gene transcription. Since the insulin receptor mRNA is not an abundant gene product we employed the sensitive run-off method of Groudine et al. (27) developed for oncogenes. In these run-off studies we employed four controls. (a) Nonspecific hybridization was minimal, as assessed by the absence of a signal with the control plasmid $\mathrm{pBr} 327$. (b) Whereas dexamethasone increased the transcription of the insulin receptor gene, it did not increase the signal for $\beta$-actin, a protein whose mRNA levels are not influenced by the glucocorticoid (12). (c) When $\alpha$ amanitin, an inhibitor of RNA polymerase II (30) was added to the nuclear incubations, the hybridization signal from runoff products was markedly reduced. $(d)$ The preincubation of the insulin receptor plasmid with sense-stranded cRNA (in contrast to antisense-stranded cRNA) markedly inhibited the hybridization signal. Since mRNA is sense-stranded, the competition of the labeled run-off products by unlabeled sensestranded cRNA indicated the specificity of the run-off assays.

The dose response of dexamethasone induction of insulin receptor gene transcription is in agreement with the dose response for steady state mRNA levels, both functions being one-half maximal at $5 \mathrm{nM}$ and maximal at $100 \mathrm{nM}$. The time needed to observe maximal stimulation of transcription was more rapid than the time needed to observe maximal stimulation of steady state mRNA levels. This observation is not surprising since increased RNA transcription must precede increased steady state mRNA levels. These rapid effects of dexamethasone on insulin receptor gene transcription provides further evidence that glucocorticoids exert a direct effect upon the insulin receptor gene. The time course for induction of insulin receptor gene transcription by glucocorticoids (maximal effect at $2 \mathrm{~h}$ ) is similar to that observed for other directly regulated genes including mouse mammary tumor virus and metallothionein $(33,34)$.

It has been established that after entry into cells glucocorticoids bind to specific receptors, and the activated ligand-receptor complex then binds to specific GREs on target genes $(13-15,35)$. These GREs have the properties of enhancer elements (36). It has now been established that the glucocorticoid GREs on DNA are comprised of conserved consensus sequences (36-38). These GREs may be either close to the promoter region or over $2 \mathrm{~kb}$ from the promoter region (39). Although these GRE sequences are generally in $5^{\prime}$ regulatory regions of the gene, GREs may be elsewhere as in the case of the human growth hormone gene where the GRE is in the first intron (40). Our computer analysis of the entire cDNA for the insulin receptor (as well as genomic and intron DNA within 1 $\mathrm{kb}$ of the AUG codon) revealed no potential GRE sites. Thus we are currently examining both $5^{\prime}$ genomic regions and introns of the insulin receptor gene to establish the presence of GRE sequences.

\section{Acknowledgments}

We would like to thank Dr. M. Groudine for his advice on transcription assays.

This work was supported by National Institutes of Health grant DK26667, the Juvenile Diabetes Foundation, and the Elise Stern Haas Fund and the Department of Medicine at Mount Zion Hospital and Medical Center.

\section{References}

1. Goldfine, I. D. 1981. Effects of insulin on intracellular functions. In Biochemical Actions of Hormones. Vol. 8. G. Litwack, editor. Academic Press, Inc., New York. 273-305.

2. Freychet, P., J. Roth, and D. M. Neville, Jr. 1971. Insulin recep- 
tors in the liver. Specific binding of $\left[{ }^{125} \mathrm{I}\right]$ insulin to the plasma membrane and its relation to insulin bioactivity. Proc. Natl. Acad. Sci. USA. 68:1833-1837.

3. Jacobs, S., and P. Cuatrecasas. 1981. Insulin receptor: structure and function. Endocrinol. Rev. 2:251.

4. Bar, R. S., L. C. Harrison, M. Muggeo, P. Gorden, C. R. Kahn, and J. Roth. 1979. Regulation of insulin receptors in normal and abnormal physiology in humans. In Advances in Internal Medicine. G. Storelman, editor. Year Book Publishers, Chicago.

5. Olefsky, J. M. 1980. Insulin resistance and insulin action. An in vitro and in vivo perspective. Diabetes. 30:148-162.

6. Czech, M. P. 1985. The nature and regulation of the insulin receptor: structure and function. Annu. Rev. Physiol. 47:357-381.

7. Kahn, C. R. 1985. The molecular mechanisms of insulin action. Annu. Rev. Med. 36:429-451.

8. Ullrich, A., J. R. Bell, E. Y. Chen, R. Herrera, L. M. Petruzzelli, T. J. Dull, P. A. Gray, L. Coussens, Y. C. Lia, M. Tsubokawa, A. Mason, P. H. Seeburg, C. Grundeld, O. M. Rosen, and J. Ramachandran. 1985. Human insulin receptor and its relationship to the tyrosine kinase family of oncogenes. Nature (Lond.). 313:756-761.

9. Ebina, Y., L. Ellis, K. Jarnagin, M. Edery, L. Graf, E. Clauser, J.-H. Ou, F. Masiarz, Y. W. Kahn, I. D. Goldfine, R. A. Roth, and W. J. Rutter. 1985. The human insulin receptor cDNA: the structural basis for hormone-activated transmembrane signalling. Cell. 40:747758.

10. Salhanick, A. I., M. N. Krupp, and J. M. Amatruda. 1983. Dexamethasone induces insulin receptor synthesis in cultured rat hepatocytes. J. Biol. Chem. 258:14130-14135.

11. Rouiller, D. G., A. McElduff, J. A. Hedo, and P. Gorden. 1985. Induction of the insulin proreceptor by hydrocortisone in cultured lymphocytes (IM-9 line). J. Clin. Invest. 76:645-649.

12. McDonald, A. R., B. A. Maddux, Y. Okabayashi, K. Y. Wong, D. M. Hawley, C. D. Logsdon, and I. D. Goldfine. 1987. Regulation of insulin receptor mRNA levels by glucocorticoids. Diabetes. 36:779781.

13. Yamamoto, K. R. 1985. Steroid receptor regulated transcription of specific genes and gene networks. Annu. Rev. Genet. 19:209252.

14. Bourgeois, S., and J. C. Gasson. 1985. Genetic and epigenetic basis of glucocorticoid resistance in lymphoid cell lines. In Biochemical Actions of Hormones. Vol. 12. G. Litwack, editor. Academic Press, Inc., Orlando, FL. 311-351.

15. Hollenberg, S., C. Weinberger, E. S. Ong, G. Carell, E. B. Thompson, M. G. Rosenfeld, and R. M. Evans. 1985. The primary structure and expression of a functional human glucocorticoid receptor cDNA. Nature (Lond.). 318:635-641.

16. Park, I., and A. Axel. 1987. Glucocorticoids enhance stability of human growth hormone mRNA. Mol. Cell. Biol. 7:1496-1507.

17. Brock, M. L., and D. J. Shapiro. 1983. Estrogen stabilizes vitellogenin mRNA against cytoplasmic degradation. Cell. 34:207214.

18. Chomezynski, P., P. Qasba, and Y. J. Topper. 1986. Transcriptional and post-transcriptional roles of glucocorticoid in the expression of the rat 25,000 molecular weight casein gene. Biochem. Biophys. Res. Commun. 134:812-818.

19. Fulton, R., and G. E. Birnie. 1985. Post-transcriptional regulation of rat liver gene expression by glucocorticoids. Nucleic Acids Res. 13:6467-6482.

20. Nawa, K., T. Nakamura, A. Kumatari, C. Noda. and A. Ichihara. 1986. Glucocorticoid-dependent expression of the albumin gene in adult rat hepatocytes. J. Biol. Chem. 261:16883-16888.

21. Lizardi, P. M. 1983. Methods for the preparation of messenger RNA. Methods Enzymol. 96:24-38.

22. Palmiter, R. D. 1974. Magnesium precipitation of ribonucleoprotein complexes. Biochemistry. 13:3606-3615.

23. Chirgwin, J. M., A. E. Przybyla, R. J. McDonald, and W. J.
Rutter. 1979. Isolation of biologically active ribonucleic acid from sources enriched in ribonuclease. Biochemistry. 24:5294-5299.

24. Thomas, P. S. 1980 . Hybridization of denatured RNA and small DNA fragments transferred to nitrocellulose. Proc. Natl. Acad. Sci. USA. 77:5201-5202.

25. Shaw, D. J., and G. I. Bell. 1985. Rsal polymorphism at the insulin receptor locus (INSR) on chromosome 19. Nucleic Acids Res. 13:8659-8661.

26. Fluke, M., K. J. Dennis, and H. Bush. 1981. Characterization of cloned rat ribosomal DNA fragments. Mol. Gen. Genet. 182:25-30.

27. Thompson, C. B., P. B. Challoner, P. E. Neiman, and M. Groudine. 1986. Expression of the c-myb proto-oncogene during cellular proliferation. Nature (Lond.). 319:374-380.

28. Cleveland, D. W., M. A. Lopata, R. A. MacDonald, N. J. Cowan, W. J. Rutter, and M. W. Kirschner. 1980. Number and evolutionary conservation of alpha- and beta-tubulin and cytoplasmic beta and gamma-actin genes using specific cloned cDNA probes. Cell. 20:95-105.

29. Melton, D. A., P. A. Krieg, M. R. Rebagliati, T. Maniatis, K. Zinn, and M. R. Green. 1984. Efficient in vitro synthesis of biologically active RNA and RNA hybridization probes from plasmids containing a bacteriophage SPG promoter. Nucleic Acids Res. 12:70357056.

30. McKnight, G. S., and R. D. Palmiter. 1979. Transcriptional regulation of the ovalbumin and conalbumin genes by steroid hormones in the chick oviduct. J. Biol. Chem. 254:9050-9058.

31. Granner, D., T. Andreone, K. Sasaki, and E. Beale. 1983. Inhibition of transcription of the phosphoenolpyruvate carbosykinase gene by insulin. Nature (Lond.). 305:349-351.

32. Addison, W. R., and D. T. Kurtz. 1986. Nucleotide sequence required for the regulation of a rat $\alpha-2 \mu$ globulin gene by glucocorticoids. Mol. Cell. Biol. 6:2334-2346.

33. Ringold, G. M., K. R. Yamamoto, G. M. Tomkins, J. M. Bishop, and H. E. Varmus. 1985. Dexamethasone-mediated induction of mouse mammary tumor virus RNA: a system for studying glucocorticoid action. Cell. 6:299-305.

34. Karin, M., R. D. Andersen, E. Slater, K. Smith, and H. R. Herschman. 1980. Metallothionein mRNA induction in HeLa cells in response to zinc or dexamethasone is a primary induction response. Nature (Lond.). 286:295-297.

35. Payvar, R., O. Wrange, J. Carlstedt-Duck, S. Okret, J. A. Gustafsson, and K. R. Yamamoto. 1981. Purified glucocorticoid receptors bind selectively in vitro to a cloned DNA fragment whose transcription is regulated by glucocorticoids in vivo. Proc. Natl. Acad. Sci. USA. 78:6628-6632.

36. Chandler, V. L., B. A. Maler, and K. R. Yamamoto. 1983. DNA sequences bound specifically by glucocorticoid receptor in vitro render a heterologous promoter hormone responsive in vivo. Cell. 33:489-499.

37. Karin, M., A. Haslinger, H. Holtgreve, R. I. Richards, P. Krauter, H. M. Westphal, and M. Beato. 1984. Characterization of DNA sequences through which cadmium and glucocorticoid hormones induce human metallothionein-11 gene. Nature (Lond.). 308:513-519.

38. Payvar, F. P., D. DeFranco, G. L. Firestone, B. Edger, O. Wrange, S. Okret, J.-A. Gustafsson, and K. R. Yamamoto. 1983. Sequence-specific binding of glucocorticoid receptor to MTV DNA at sites within and upstream of the transcribed region. Cell. 35:381-392.

39. Jantzen, H.-M., V. Strahle, B. Gloss, F. Stewart, W. Schmid, M. Boshart, R. Miksicele, and G. Schutz. 1987. Cooperativity of glucocorticoid response elements located for upstream of the tyrosine aminotransferase gene. Cell. 49:29-38.

40. Moore, D. D., A. R. Marks, D. I. Bucklay, G. Kapler, F. Payvar, and H. M. Goodman. 1985. The first intron of the human growth hormone gene contains a binding site for the glucocorticoid receptor. Proc. Natl. Acad. Sci. USA. 82:699-702. 